\title{
Bird species composition and diversity in habitats with different disturbance histories at Kilombero Wetland, Tanzania
}

\author{
Wilbard A. Ntongani, Samora M. Andrew* \\ Department of Forest Biology, Faculty of Forestry and Nature Conservation, Sokoine University of Agriculture, Morogoro, Tanzania; \\ Corresponding Author: smacrice@suanet.ac.tz
}

Received 1 October 2013; revised 1 November 2013; accepted 8 November 2013

Copyright (C) 2013 Wilbard A. Ntongani, Samora M. Andrew. This is an open access article distributed under the Creative Commons Attribution License, which permits unrestricted use, distribution, and reproduction in any medium, provided the original work is properly cited.

\begin{abstract}
Wetland natural grasslands are important habitats for avian populations throughout the world. Unfortunately the increase of human population and rise in demand for settlements and agricultural land have degraded these habitats in many tropical wetlands. To effectively restore these natural grasslands and conserve avifaunal biodiversity, understanding of the relationships between habitat conditions and bird community structure are central. We used a combination of information from nearby villagers and field surveys to establish two important grassland habitats with low and high disturbance histories, and related the habitats to bird community structure. We surveyed a total of $\mathbf{1 1 9}$ sites in the two habitats to examine variation in the abundance, richness, diversity and composition of birds at Kilombero Wetland Tanzania. In total, 3049 individuals, 126 species, 88 genera and 45 families were recorded from Kilombero grasslands. Our results show that grasslands with low human disturbance had more number of bird species, genera, families and diversity (both ShannonWiener and Simpson) than the most disturbed grasslands at $p<0.05$. However, the abundance and Shannon evenness of birds were not different $(p>0.05)$ between low and highly disturbed grassland habitats suggesting that other factors including variety of foraging sites are important. This study confirms that the wetland grasslands of Kilombero are important for conservation of birds including rare and endemic species. It is recommended that anthropogenic disturbances should be minimized including con-
\end{abstract}

trol of fire, regulation of agricultural activities and population of cattle within the wetland system to restore and conserve biodiversity.

Keywords: Natural Habitats; Simplified Landscapes; Anthropogenic Disturbance; Richness; Biodiversity; Kilombero; Tanzania

\section{INTRODUCTION}

Increasingly, human population growth coupled with the rise in demand for settlements, agricultural land and wood products is altering important wildlife habitats, bird diversity patterns and overall biodiversity around the world [1-3]. In wetlands, the use and cover of grassland natural habitats have been unprecedentedly altered $[4,5]$ and unfortunately the impacts of these changes on bird community composition, structure and diversity are yet to be fully understood. It should however be remembered that the failure to understand the consequence of changes in these natural habitats on wetland biodiversity is likely to increase the human pressure on wetland natural resources including birds [6].

Wetlands are important ecosystems appreciated for providing quality and abundant habitats for avifauna populations throughout the year and thus a considerable number of wetlands are declared as important bird areas [7]. Nevertheless, wetlands are among the most threatened ecosystems $[8,9]$ as the size, quality and structure of their habitats have been altered by anthropogenic disturbances such as intensive agriculture and livestock overgrazing. Moreover, climate change may exacerbate further wetlands natural resources degradations [10], consequently affecting negatively the abundance, diversity and community composition of especially threatened bird species [11]. While it does not necessarily allow 
generalization across all ecosystems and regions, evidence from many empirical studies suggest that disturbed and modified habitats harbour less avian biodiversity as compared to natural habitats because the later provides more resources [12,13]. Thus, effective management strategies should aim to restore these degraded habitats and simplified landscapes especially in the tropics where there is a dearth of information on birds' population dynamics in relation to anthropogenic disturbances.

Kilombero wetland in Tanzania provides abundant and diverse habitats for variety of bird species, and is recognized internationally as an Important Bird Area (IBA) and a Ramsar site [14]. According to the Ramsar wise use principle, Ramsar sites can be used as long as the use is compatible with their ecological characters, and all the uses are for sustainable development [15]. Contrary to the wise use principle, unregulated anthropogenic activities such as unplanned settlement development, intensive agriculture and overgrazing by livestock are on the rise at Kilombero [5,16]. This is increased concerns over the ecological integrity and sustainability of this important ecosystem [16,17], and if not counterchecked with management interventions the wetland ecosystem structure and functions may be impaired. Birds are acknowledged to be ecosystems health indicators worldwide [18,19] and could facilitate understanding and prediction of consequences of human disturbances to the wetland biodiversity. However, studies looking at how bird species composition, abundance, richness and diversity vary between grasslands with different disturbance histories in semi-protected wetlands are not common in this region. Therefore lack of these studies impedes effective restoration and biodiversity conservation efforts. This study aims to broadly understand the potential consequences of land use change on bird community dynamics, and suggest mitigation strategies to restore the tropical wetlands. We therefore specifically set out to study the variation of bird species composition, abundance, richness and diversity between two grassland habitats with different disturbance histories (low and high disturbances). We predicted that 1) grassland habitats with different disturbance histories would support different bird species and 2) a less disturbed habitat would support more species diversity consistent with other studies [12,20].

\section{MATERIALS AND METHODS}

\subsection{Study Area}

The study was conducted in the Kilombero Valley Floodplain Wetland in Morogoro region, southern-central Tanzania. Situated between $8^{\circ} 40^{\prime} 0^{\prime \prime} \mathrm{S}$ and $36^{\circ} 10^{\prime} 0^{\prime \prime} \mathrm{E}$ and covering an area of $7967 \mathrm{~km}^{2}$, Kilombero wetland is a Ramsar site and an Important Bird Area (IBA) with high biodiversity [14]. Kilombero valley is included in the
Greater Selous Ecosystem, a World Heritage Site. The area experiences a tropical sub-humid climate and has a bimodal rainfall pattern with short rains between December and February and long rains between March and May [21]. The average annual rainfall is $1200-1400 \mathrm{~mm}$ whereas the mean annual temperature is $26^{\circ} \mathrm{C}$ [22]. Kilombero wetland holds above 300 unique and diverse bird species on regular basis [11,23] and could hold up to 20,000 waterbirds during wet season [14]. There are grasslands, papyrus and woodland vegetations with a total of about 350 plant species in the wetland system [24]. However, in this study we focused on the grasslands where we identified two habitats with low and high disturbance histories.

\subsection{Habitat Data}

We combined information from the nearby villagers and preliminary field surveys to establish bird habitats with different disturbance histories at Kilombero. We surveyed 60 sites in the high and 59 sites in the low disturbed grassland habitats. A high disturbed habitat is located at the periphery of the valley close to human settlements and is characterised by open short grasslands which are intensively grazed by cattle and few crop fields. Fire is also common during dry season in this habitat especially from August to October. Grasses such as Echinochloa colona and Paspalum scrobiculatum and forb species such as Hygrophila auriculata and Chamaecrista mimosoides are present. A few trees particularly sausage tree (Kigelia africana) occasionally occurred on few available termite mounds. According to the villagers who have lived in that area for at least twenty years, this habitat have had annual fires and overgrazing for at least 15 years. On the other hand, low disturbed habitat is located at a distance from the border of the valley. It is characterized by a combination of short and long natural grasses and a perennial grass $\mathrm{Pa}$ nicum fluviicola is abundant. In this habitat, species such as Ipomoea aquatic, Eragrostis aethiopica and Sida ovata are also present. Villagers confirmed that because of its distance from the human settlements and relatively moist grasses especially during dry season fire is not common, no crop fields and there is occasional grazing is this habitat (mainly during dry season). These descriptions for habitats are also supported by [24], and the size of these two habitats is somewhat comparable. In total we surveyed 119 sites from low and high disturbed grassland habitats.

\subsection{Bird Species Survey}

We used distance sampling method [6] to gather information on bird species abundances and identities during the dry season of 2010. During the surveys, birds were 
identified early in the morning from 6.00 to 10.00 hours and late afternoon from 16.00 to 18.30 hours when the temperature was relatively cool and bird's activities were high [6]. Birds were identified with the aid of two field experienced staff and field guide books [25]. On every site, we recorded all birds seen or heard during 15 minutes. The first five minutes were used to wait until bird species were settled due to arrival disturbances and the remaining ten minutes were used to record all species observed or heard. On every occasion, the distances to all birds were determined using a calibrated range finder and we restricted the distance to around $50 \mathrm{~m}$ for identification purposes. Birds that flew overhead but did not land in the sites were not recorded [26].

\subsection{Statistical Analyses}

We computed the abundance, richness (species, genus and family), Shannon evenness $\left(J^{\prime}\right)$, Shannon-Wiener diversity $\left(H^{\prime}\right)$ and Simpson's index of dominance $\left(D^{\prime}\right)$. To determine the abundance of birds in a site and habitat, we added all individual birds. Species richness $(S)$ was obtained by adding the number of species present. To obtain genus and family richness, we added the number of genera and families in each site for the respective habitat. To obtain bird abundance in a habitat, we added all individual birds from all the sites in that particular habitat. Shannon-Wiener and Simpson diversity indices were computed using Biodiversity $R$ package [27]. Evenness, the distribution of abundances among species was computed as $J^{\prime}=H^{\prime} / \ln S$ whereas $S$ is the number of species in the site [28]. Evenness ranges from 0 to 1 and as it approaches 1 , individuals are partitioned equally among species. High values of $H^{\prime}$ and low values of $D^{\prime}$ indicate high species diversity. Data were log transformed to improve normality and homogeneity of variance [29]. To calculate beta-diversity (difference in community com- position between marginal and valley grasslands) we used Jaccard index [30]. To obtain relative abundances of most common birds in the two habitats, we summed the individuals in each species and the relative abundances were presented as a proportion of total individuals in the respective habitat. We tested for differences in bird abundance, richness, evenness and diversity between low and high disturbed habitats using independent t-tests. Correlation analyses were used to establish associations between diversity measures in the two habitats using $\mathrm{R}$ statistical environment version 2.13.1 [31].

\section{RESULTS}

We found at least one bird species on every site we surveyed (Table 1). The overall most abundant site had 236 individuals and interestingly the site was on high disturbed habitat. On the contrary, low disturbed grassland sites had the highest number of species and genus with seven and five mean species and genera, respecttively (Table 1). Also, species richness $(t=6.52, p<$ $0.001)$, genus richness $(t=6.20, p<0.001)$ and family richness $(t=3.98, p<0.001)$ were significantly higher on low than on high disturbed grasslands (Table 1). We found that the mean genus richness on low disturbed grasslands was almost twice higher the mean genus richness of high disturbed grasslands (Table 1). The Shannon-Wiener $(t=4.47, p<0.001)$ and Simpson diversity $(t=4.84, p<0.001)$ indices were significantly higher on low than on high disturbed grasslands (Table 1). The low disturbed grasslands had higher ShannonWiener diversity than the highly disturbed grasslands sites by 1.63 . There were no significant differences in the abundance of bird species between high and low disturbed grasslands $(t=0.52, p=0.607)$, nor did Shannon evenness index for birds differ between high and low disturbed habitats $(t=0.72, p=0.473)$. The Jaccard

Table 1. Differences in diversity measures (means \pm SD) of bird community between high and low disturbed grasslands of Kilombero wetland, Morogoro, Tanzania. Values in parenthesis for abundance and diversity measures are minimum and maximum values in surveyed sites for each grassland habitat.

\begin{tabular}{llc}
\hline \multicolumn{1}{c}{ Diversity measures } & \multicolumn{2}{c}{ Grassland habitats } \\
\cline { 2 - 3 } & High $(n=60)$ & Low $(n=59)$ \\
\hline Abundance & $24 \pm 35(1,236)$ & $27 \pm 28(2,103)$ \\
Species richness & $4 \pm 2(1,9)$ & $7 \pm 3(1,15)$ \\
Genus richness & $2.52 \pm 1.6(1,7)$ & $4.78 \pm 2.3(1,10)$ \\
Family richness & $1.55 \pm 0.14(1,4)$ & $2.54 \pm 1.6(1,6)$ \\
Shannon evenness index $\left(J^{\prime}\right)$ & $0.75 \pm 0.23(0.26,1)$ & $0.79 \pm 0.24(0.34,0.98)$ \\
Shannon-Wiener diversity $\left(H^{\prime}\right)$ & $0.84 \pm 0.55(0.21,1.95)$ & $<0.001$ \\
Simpson diversity $\left(D^{\prime}\right)$ & $0.45 \pm 0.28(0.1,0.86)$ & 0.473 \\
\hline
\end{tabular}


indices for species, genera and families were $34.1 \%$, $48.8 \%$ and $60.9 \%$ respectively, between high and low disturbed grassland habitats.

A total of 3049 individuals, 126 species, 88 genera and 45 families were recorded from 119 sites within the two grassland habitats (Table 2). Of all counted bird species, a considerable number of species including the endemic species of Ploceus burnieri and Kilombero Cisticola (undescribed) were recorded in both habitats (Table 2). A total of 69 and 100 species were recorded for high and low disturbed grassland habitats. Of the 69 species recorded from high disturbed grasslands, 26 were restricted to only this habitat. Fifty seven species were exclusively found on low disturbed grasslands (Table 2).

Two most frequent species on high disturbed grasslands were Euplectes axillaris and E. nigroventris with $36 \%$ and $26 \%$ relative abundances whereas, the low disturbed grassland was dominated by Euplectes axillaris and Anastomus lamelligerus with $13.7 \%$ and $10.4 \%$ relative abundances, respectively (Table 3). Families of Fribgillidae, Nectariniidae and Passeridae were found only on the high disturbed grasslands. Similarly, families of Acrocephalidae, Anatidae, Anhingidae, Ciconiiformes, Dicruridae, Glareolidae, Halcyonidae, Jacanidae, Locustellidae, Pelecanidae, Rallidae, Recurvirostridae, Rynchopidae and Threskiornithidae were restricted only to the low disturbed grassland habitat, respectively.

Table 2. Summary of total bird community data in different grassland habitats at Kilombero wetland, Morogoro, Tanzania.

\begin{tabular}{lcccc}
\hline \multirow{2}{*}{ Parameter } & \multicolumn{4}{c}{ Grassland habitats } \\
\cline { 2 - 5 } & High & Low & Total & $\begin{array}{c}\text { Values shared } \\
\text { between habitats }\end{array}$ \\
\hline $\begin{array}{l}\text { Number of } \\
\text { individuals }\end{array}$ & 1448 & 1601 & 3049 & \\
$\begin{array}{l}\text { Number of } \\
\text { species }\end{array}$ & 69 & 100 & 126 & 43 \\
$\begin{array}{l}\text { Number of } \\
\text { genus }\end{array}$ & 56 & 75 & 88 & 43 \\
$\begin{array}{l}\text { Number of } \\
\text { family }\end{array}$ & 31 & 42 & 45 & 28 \\
\hline
\end{tabular}

Table 3. The relative abundance of four most common bird species at different grassland habitats of Kilombero wetland, Morogoro, Tanzania.

\begin{tabular}{lllc}
\hline \multirow{2}{*}{ Species } & \multirow{2}{c}{ Family } & \multicolumn{2}{c}{$\begin{array}{c}\text { Abundance in grassland } \\
\text { habitats (\%) }\end{array}$} \\
\cline { 3 - 4 } & & High & Low \\
\hline Anastomus lamelligerus & Ciconiidae & 0.50 & 10.4 \\
Bubulcus ibis & Ardeidae & 0.14 & 9.0 \\
Euplectes nigroventris & Ploceidae & 26.0 & 8.3 \\
Euplectes axillaris & Ploceidae & 36.0 & 13.7 \\
\hline
\end{tabular}

The first six families with the overall highest number of taxa were Estrildidae (8 genera, 11 species), Ardeidae (6 genera, 11 species), Charadriidae (2 genera, 8 species) Ploceidae (3 genera, 6 species), Cisticolidae (4 genera, 8 species) and Alcedinidae (4 genera, 5 species). The genera with the highest number of bird species were Vanellus (V. albiceps, V. armatus, V. senegallus, V. spinosus, and V. crassirostris) and Cisticola (C. ayresii, C. brachypterus, C. chiniana, and C. Fulvicapillus) and Ardea with 4 species (A. cinerea, A. goliath, A. melanocephala and $A$. purpurea). The high disturbed grassland habitat was mostly dominated by Accipitridae ( 8 genera, 8 species) and Estrildidae (6 genera, 8 species) families, whereas low disturbed grasslands was mostly dominated by Ardeidae (2 genera, 6 species) and Charadriidae (1 genera, 5 species) families showing that there were differences in family composition for the two habitats. Shannon-Wiener diversity and Simpson diversity of dominance did not relate (Pearson Product Moment Correlation, all $r<0.20$ and all $p>0.05$ ) with the abundance of bird species for both high and low disturbed grasslands (Table 4). There were no correlations between Shannon evenness and the richness of species, genus and family for low disturbed grasslands (all $r<0.15$ and all $p>$ $0.05)$, whereas for high disturbed grasslands the Shannon evenness related (all $r>0.50$ and all $p<0.05$ ) with species, genus and family richness (Table 4 ).

\section{DISCUSSION}

This study has revealed that both low and high disturbed grasslands provide important habitats that support a considerable number of bird species including endemic species of Ploceus burnieri. Overall these grasslands support at least 126 bird species which are almost $42 \%$ of all birds reported in the area [23]. Our findings that grasslands support a significant number of bird species is consistent with other studies elsewhere in the tropics [19,32-34]. We predicted that habitats with different human disturbance histories would support different bird species. Indeed our results show that the two grassland habitats supported different bird species. About 38\% and $57 \%$ of all birds recorded had strict occurrence on high and low disturbed grasslands, respectively. However, other species (e.g. Ploceus burnieri, Euplectes axillaris, Anastomus lamelligerus and Bubulcus ibis) were found on both habitats suggesting that they use wide range of habitats possibly because of rich dietary guilds in this system [35].

Consistent with our second prediction, the number of species, genera, families and species diversity was significantly higher on low disturbed than on high disturbed grassland habitats. This is in line to a study in South Africa at Mpumalanga which reported that human disturbance (especially bush fires and livestock grazing) 
Table 4. Pearson correlation coefficients of diversity measures for bird species at grassland habitats of Kilombero wetland, Morogoro, Tanzania. Coefficient values in parentheses are values for valley grasslands while other values are for marginal grasslands.

\begin{tabular}{|c|c|c|c|c|c|c|}
\hline & Abundance & Species richness & Genus richness & Family richness & Shannon evenness & Shannon diversity \\
\hline \multicolumn{7}{|l|}{ Abundance } \\
\hline Species richness & $\begin{array}{c}0.28 \\
(0.64)\end{array}$ & & & & & \\
\hline Genus richness & $\begin{array}{c}0.15 \\
\mathbf{( 0 . 5 7 )}\end{array}$ & $\begin{array}{c}0.91 \\
(0.90)\end{array}$ & & & & \\
\hline Family richness & $\begin{array}{c}0.07 \\
\mathbf{( 0 . 5 0 )}\end{array}$ & $\begin{array}{c}\mathbf{0 . 8 0} \\
(\mathbf{0 . 7 5})\end{array}$ & $\begin{array}{c}0.81 \\
(\mathbf{0 . 7 5})\end{array}$ & & & \\
\hline Shannon evenness & $\begin{array}{c}-0.10 \\
(-\mathbf{0 . 4 8})\end{array}$ & $\begin{array}{c}\mathbf{0 . 5 1} \\
(-0.12)\end{array}$ & $\begin{array}{c}\mathbf{0 . 5 6} \\
(-0.09)\end{array}$ & $\begin{array}{c}\mathbf{0 . 5 1} \\
(-0.03)\end{array}$ & & \\
\hline Shannon-Wiener diversity & $\begin{array}{c}0.01 \\
(-0.14)\end{array}$ & $\begin{array}{c}0.84 \\
(0.37)\end{array}$ & $\begin{array}{c}0.83 \\
(0.35)\end{array}$ & $\begin{array}{c}0.73 \\
(0.33)\end{array}$ & $\begin{array}{c}0.85 \\
(\mathbf{0 . 8 1})\end{array}$ & \\
\hline Simpson functional diversity & $\begin{array}{c}-0.02 \\
(-0.19)\end{array}$ & $\begin{array}{c}0.74 \\
(0.41)\end{array}$ & $\begin{array}{c}0.74 \\
(0.38)\end{array}$ & $\begin{array}{c}0.65 \\
(0.29)\end{array}$ & $\begin{array}{c}0.94 \\
(0.40)\end{array}$ & $\begin{array}{c}0.97 \\
(0.53)\end{array}$ \\
\hline
\end{tabular}

Statistical significant correlations $(P<0.05)$ are shown with bold numbers.

reduced bird species richness and density [32].

In another study in Australia, [36] reported that high grazing in riparian habitats was negatively related to the density and richness of bird species. During the last few decades, the presence of permanent water, fertile soils and good pasture has attracted farmers and pastoralists from other parts of Tanzania to Kilombero wetland [16, 22]. Fire is also common during dry season in the grasslands [5,24], and all these unregulated anthropogenic disturbances impacts negatively the grassland habitats and birds' composition, richness and diversity at Kilombero. Our study shows that the abundance and evenness of bird species were not statistically different between the two grassland habitats, suggesting that these community properties are apparently not influenced by human disturbance. This finding is in agreement with another short time experimental study conducted in Kenya, where fire did not have effect on total abundance of birds [26]. At Kilombero grasslands, it could be that other ecological factors including the availability of variety of foraging sites determines the abundance and evenness of bird species [11].

It appears that human-induced disturbances and possibly presence of variety of foraging sites contribute to the variation of abundance, composition, richness and diversity of bird species in our area. This study showed that a highly disturbed habitat supported less bird species richness and diversity than low disturbed habitat. It is widely known that disturbance of natural habitats leads to reducetion or loss of habitat depended species, and most likely to survive are the generalist species [13]. At Kilombero, it is likely that prolonged anthropogenic disturbances have altered biologically or structurally the conditions of the most disturbed grasslands, consequently these grasslands support less bird species. In another study at our system, it was revealed that livestock encroachment affects negatively wildlife species especially large mammals [21], and this suggests that not only large mammals but birds are also negatively affected by especially overgrazing $[32,36]$. Continued intensification of human disturbances will affect mostly birds with restricted-range and IUCN Red-Data Book species [7]. It is therefore recommended that anthropogenic disturbances be minimized through for example control of fire, agricultural activities regulation and restriction of population of cattle and their movements within the wetland system to restore and conserve biodiversity.

\section{ACKNOWLEDGEMENTS}

This study was funded by The Department of Forest Biology, Sokoine University of Agriculture Morogoro, Tanzania.

\section{REFERENCES}

[1] Julliard, R., Jiguet, F. and Couvet, D. (2003) Common birds facing global changes: What makes a species at risk? Global Change Biology, 10, 148-154. http://dx.doi.org/10.1111/j.1365-2486.2003.00723.x

[2] Miller, J.R., Wiens, J.A., Hobbs, N.T. and Theobald, D.M. (2003) Effects of human settlement on bird communities in lowland riparian areas of Colorado (USA). Ecological Applications, 13, 1041-1059. http://dx.doi.org/10.1890/1051-0761(2003)13[1041:EOH $\underline{\mathrm{SOB}] 2.0 . \mathrm{CO} ; 2}$

[3] Andrew, S., Maliondo, S., Mtika, J., Msanga, H. P. and Nsolomo, V. R. (2004) Growth performance of Azadirachta indica provenances in Morogoro, Tanzania. Journal of Tropical Forest Science, 16, 328-335.

[4] Toogood, S., Joyce, C. and Waite, S. (2008) Response of floodplain grassland plant communities to altered water regimes. Plant Ecology, 197, 285-298. 
http://dx.doi.org/10.1007/s11258-007-9378-6

[5] Andrew, S.M., Moe, S.R., Totland, Ø. and Munishi, P.K.T. (2012) Species composition and functional structure of herbaceous vegetation in a tropical wetland system. Biodiversity Conservation, 21, 2865-2885. http://dx.doi.org/10.1007/s10531-012-0342-y

[6] Bibby, C.J., Burgess, N.D., Hill, D.A. and Mustoe, S.H. (2000) Bird census techniques. Academic Press, London.

[7] Bird Life International (2012) IUCN red list for birds. http://www.birdlife.org

[8] Millenium Ecosystem Assessment (2005) Ecosystems and human well-being: Wetlands and water-synthesis. World Resource Institute, Washington DC.

[9] Zedler, J.B. and Kercher, S. (2005) Wetland resources: Status, trends, ecosystem services and restorability. Annual Review of Environmental Research, 30, 39-74. http://dx.doi.org/10.1146/annurev.energy.30.050504.1442 $\underline{48}$

[10] Parry, M.L. (2007) Climate change impacts, adaptation and vulnerability: Contribution of working group II to the fourth assessment report of the intergovernmental panel on climate change. Cambridge University, Cambridge.

[11] Baker, N.E. and Baker, E.M. (2002) Important bird areas in Tanzania. A first inventory. Wildlife Society of Tanzania, Dar es salaam Tanzania.

[12] Hill, D., Hockin, D., Price, D., et al. (1997) Bird disturbance: Improving the quality and utility of disturbance research. Journal of Applied Ecology, 34, 275-288. http://dx.doi.org/10.2307/2404876

[13] Green, D.M. and Baker, M.G. (2003) Urbanization impacts on habitat and bird communities in a Sonoran desert ecosystem. Landscape and Urban Planning, 63, 225-239. http://dx.doi.org/10.1016/S0169-2046(02)00195-0

[14] Ramsar (2013) The Ramsar convection on wetlands database.

http://ramsar.wetlands.org/Database/AbouttheRamsarSite sDatabase/tabid/812/Default.aspx

[15] Ramsar (1971) The Ramsar convention. Center, R. Rue Mauverney 28, CH 1196, Gland.

[16] Booth, V.R., Njuguna, S., Njue, E., Enyola, M. and Masurelle, V. (2008) The development and implementation of an integrated management plan of Kilombero valley flood plain Ramsar site. Ministry of Natural Resources and Tourism, Dar es salaam, Tanzania.

[17] Mombo, F.M. (2013) A new institutional economics approach to evaluate management options for wetlands: The case of Kilombero Valley wetlands in Tanzania. Ph.D. Thesis, Ghent University, Belgium.

[18] Croonquist, M.J. and Brooks, R.P. (1991) Use of avian and mammalian guilds as indicators of cumulative impacts in riparian-wetland areas. Environmental Management, 15, 701-714.

http://dx.doi.org/10.1007/BF02589628

[19] Mahinya, S.G. (2005) Assessment of ecological integrity of land use systems using birds as bioindicators in the Malagarasi-Muyovozi Ramsar site Western Tanzania: M.Sc. Thesis, Sokoine University of Agriculture, Tanzania.
[20] Jonsson, M., Strasevicius, D. and Malmqvist, B. (2012) Influences of river regulation and environmental variables on upland bird assemblages in northern Sweden. Ecological Research, 27, 945-954.

[21] Bonnington, C., Weaver, D. and Fanning, E. (2007) Livestock and large wild mammals in the Kilombero Valley, in southern Tanzania. African Journal of Ecology, 45, 658-663. http://dx.doi.org/10.1111/j.1365-2028.2007.00793.x

[22] Kangalawe, R.Y.M. and Liwenga, E.T. (2005) Livelihoods in the wetlands of Kilombero Valley in Tanzania: Opportunities and challenges to integrated water resource management. Physics and Chemistry of the Earth, 30, 968-975. http://dx.doi.org/10.1016/j.pce.2005.08.044

[23] Rainey, H., Birnie, N., Cameron, A., Mwangomo, E. and Starkey, M. (2002) Ornithological survey. In: Starkey, M., et al., Eds., The Kilombero Valley Wildlife Project: An Ecological and Social Survey in the Kilombero Valley, Tanzania, Kilombero Wildlife Project, Edinburgh, 41101.

[24] Starkey, M., Birnie, N., Cameron, A., et al. (2002) The Kilombero Valley Wildlife project: An ecological and social survey in the Kilombero Valley, Tanzania. Edinburgh. http://biology.st-and.ac.uk/sites/kilombero/fullrep.pdf

[25] Stevenson, T., Fanshawe, J., Small, B., Gale, J. and Arlott, N. (2002) Field guide to the birds of East Africa: Kenya, Tanzania, Uganda, Rwanda, Burundi. T \& AD Poyser Ltd., London.

[26] O'Reilly, L., Ogada, D., Palmer, T.M. and Keesing, F. (2006) Effects of fire on bird diversity and abundance in an East African savanna. African Journal of Ecology, 44, 165-170. http://dx.doi.org/10.1111/j.1365-2028.2006.00601.x

[27] Kindt, R. and Coe, R. (2005) Tree diversity analysis. A manual and software for common statistical methods for ecological and biodiversity studies. World Agroforesty Centre (ICRAF), Nairobi.

[28] Magurran, A.E. and McGill, B.J. (2011) Biological diversity: Frontiers in measurement and assessment. Oxford University Press, Oxford.

[29] Sokal, R. and Rohlf, F. (1995) Biometry. 3rd Edition, WH Freman and Company, New York.

[30] Jaccard, P. (1928) Die statistisch-floristische methode als grund-lage der pflanszensoziologie. In: Abderhalden, Ed., Handbuch Biologischer Arbeitsmethoden, 11, 165-202.

[31] R Development Core Team (2011) R: A language and environment for statistical computing. R Foundation for Statistical Computing, Vienna. http://www.R-project.org

[32] Jansen, R., Little, R. and Crowe, T. (1999) Implications of grazing and burning of grasslands on the sustainable use of francolins (Francolinus spp.) and on overall bird conservation in the highlands of Mpumalanga province, South Africa. Biodiversity and Conservation, 8, 587-602. http://dx.doi.org/10.1023/A:1008817415103

[33] Brawn, J.D., Robinson, S.K. and Thompson III, F.R. (2001) The role of disturbance in the ecology and conservation of birds. Annual Review of Ecology and Systematics, 32, 251-276. 
http://dx.doi.org/10.1146/annurev.ecolsys.32.081501.114 $\underline{031}$

[34] He, C., Ishikawa, T., Sheng, L. and Irie, M. (2009) Study on the hydrological conditions for the conservation of the nesting habitat of the Red-Crowned Crane in Xianghai Wetlands, China. Hydrological Processes, 23, 612-622. http://dx.doi.org/10.1002/hyp.7189

[35] Kissling, W.D., Sekercioglu, C.H. and Jetz, W. (2012) Bird dietary guild richness across latitudes, environments and biogeographic regions. Global Ecology and Biogeography, 21, 328-340.

http://dx.doi.org/10.1111/j.1466-8238.2011.00679.x

[36] Martin, T.G. and McIntyre, S. (2007) Impacts of livestock grazing and tree clearing on birds of woodland and riparian habitats. Conservation Biology, 21, 504-514. http://dx.doi.org/10.1111/j.1523-1739.2006.00624.x 